\title{
用LB 技术获得科间植物三叶半夏和紫鸭跖草杂种再生植株
}

应用人工促使不同植物细胞间细胞质和 染色质穿壁转移技术(LB技术), 成功地获得 了带颜色标记性状的科间植物三叶半夏和紫 鸭距草杂种再生植株. 初步结果报道如下:

三叶半夏 (Pinellia ternate Brelt)，属 天南星科, 叶片为深绿色. 紫鸭跖草 (Comm elina communis), 是鸭路草科植物,地上部 分全株呈紫红色. 操作程序基本同前报道 ${ }^{[1]}$. 首先, 诱导双亲植物的分生细胞团, 离散混合 于低渗、低 $\mathrm{pHK}^{+}$活性液中处理, 紫鸭跖草 细胞作为供体 2-3 倍于三叶半夏细胞. 经 低速离心处理后增殖培养 20 天, 三叶半夏和 紫鸭跖草细胞间建立联结, 再经 $\mathrm{K}^{+}$活性液预 处理和强化离心处理, 促使细胞间细胞质和 染色质穿壁转移. 最后经修复培养和增殖培 养后在适合三叶半夏细胸分化的培养基上分 化再生植株, 共得到 23 株再生植株. 三叶半 夏细胞团直接分化及经 LB 技术处理后分化 再生植株作为对照. 经上述操作所得杂交丽 生植株中有 2 你其植株形态和叶形间三叶半
夏, 但叶呈紫红色, 颜色较紫鸭跖草浅, 靠叶 柄处约占整个叶面积 $1 / 5$ 部分仍为绿色. 未 经 LB 技术处理直接分化再生的三叶半夏植 株及经 LB 技术处理后再生的三叶半夏植株 叶片仍为绿色. 三叶半夏细胞团和再生植株 经继代培养、高温、低温及干旱等处理后没有 紫红色叶片出现. 表明紫鸭跖草细胞的部分 遗传物质经 LB 技术操作转移到了三叶半夏 细胞中并在再生植格中得到了表达. 这一结 果对 LB 技术导入外源遗传物质并获得远缘 杂种的可行性和真实性也是一个佐证。对这 一科间植物杂种的一系列生理、生化和遗传 分析正在进行中.

\section{参考文 献}

[1]吴伯弱、崔亚亚、陈教平, 中国科学, B 辑, 1987,10 : 1068-1072.

\section{崔亚亚 陈媇平吴伯聚} (中国科学院成都生物研究所, 成都 610015) 